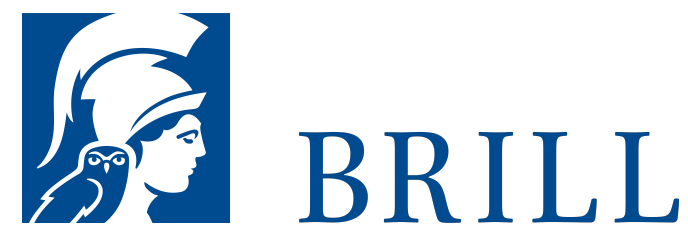

\title{
Die Erfindung des Pädagogischen
}

\section{Author: Alfred Schäfer}

Individualität, Selbstbestimmung, Identität mit sich selbst diese Konzepte verweisen auf das Verhältnis des Menschen zur Gesellschaft. Mit ihnen beerbt die moderne Fassung des Pädagogischen eine uralte Fragestellung: diejenige nach dem Ort der Subjektivität, die in ihren sozialen Einbindungen nicht aufgeht. Antworten auf diese Fragen hatten ihren Ort in kultischen Inszenierungen - etwa der Initiation - oder in metaphysischen oder religiösen Vergewisserungen, die diese Subjektivität an einen jenseitigen Grund zu binden versuchten. Dass diese Herkünfte in die Entstehung des pädagogischen Raums münden, liegt daran, dass die transzendenten Verortungsbemühungen der Subjektivität in der entstehenden Moderne nicht mehr möglich erscheinen. Zugleich aber erweist sich auch das Programm der Aufklärung, eine Selbstgründung des souveränen Subjekts, als undurchführbar. In der Reaktion auf diese Problemlage wird das Pädagogische bei Rousseau, Schiller, Humboldt, Herbart und Schleiermacher hervorgebracht: als Entwurf sakralisierter Möglichkeitsräume.

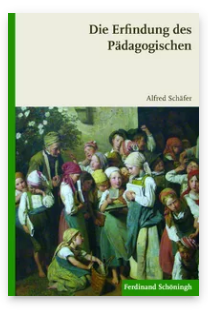

Pages: 408

Seiten

Language:

German

Subjects:

General,

Education

Publisher: Brill |

Schöningh

E-Book (PDF)

Released online:

20 Jan 2020

ISBN: $978-3-$

657-76837-0

List price

Paperback

Publication date:

o7 Oct 2009

ISBN: 978-3-

506-76837-7

List price 
For more information see brill.com

Order information: Order online at brill.com +44330 333 0049 | customerservices@brill.com Submission information: brill.com/authors

Titles published by Brill | Fink, Brill | mentis or Brill | Schöningh: +49(o)715413279216| brill@brocom.de 